\title{
Strategies Against Human Trafficking: The Role of Education In Jeneponto District, South Sulawesi, Indonesia
}

\author{
Rahmatia Yunus, Seniwati, Amanus Khalifafilardy Yunus, and Munawwarah S. Mubarak
}

\begin{abstract}
This paper focuses on the Indonesian strategies in fighting human trafficking. Indonesian migrant domestic workers are one of the highest rates of undocumented labor migration. Moreover, they also do not have skill. Therefore they are vulnerable to labor exploitation and human rights abuses. The type of work of Indonesian workers that were trafficked such as domestic service, sex work, shop keeping, waitressing, dancing and factory work. Trafficking in person both domestically and transnationally in Indonesia is an issue of concern across Indonesia's 33 provinces. South Sulawesi province also has been identified as a trafficking issue within Indonesia. Research questions namely 1) what can average person do to help to fight this crime?, 2) how can we better educate potential victims of human trafficking?. This research uses qualitative method. This method is to analysis and collects data to support the content of analysis. This research conducted in Jeneponto district, South Sulawesi Province. In beating human traffickers, education and knowledge of trafficking in person among all members of society is one of strategy. As a researcher, we try to raise awareness about the nature, causes and damage to victims. Therefore, cooperation between government, civil society, the press, and private companies in promoting knowledge of countering human trafficking are needed.
\end{abstract}

Index Terms-Education and knowledge, human trafficking, labor exploitation, migrant domestic workers, south Sulawesi province.

\section{INTRODUCTION}

Some countries have significant growth in the economies. Therefore, these countries have led to a strong demand for low-skilled labor especially from migrant workers from Southeast Asian Countries. Lan and Parrenas said that "live-in migran domestic workers are in particularly high demand, as the recruitment of migrants enables women in less developed countries to seek employment in skilled positions, instead of performing care-related and household tasks full-time" [1], [2]. The other sources said that "migrants are particularly vulnerable to labour exploitation and human rights abuses, which in some cases involve human trafficking" [3]-[10]. In cases abusive working conditions, migrant workers are especially vulnerable. Migrant workers do not have skill therefore they could be exploited such as working days or hours and low or no salary (see Fig. 1).

Manuscript received November 15, 2015; revised January 20, 2016.

The authors are with the Hasanuddin University, Makassar, South Sulawesi, Indonesia (e-mail: rahmatiayunus@gmail.com, seniwati_2006@yahoo.co.id, orfilakfy@gmail.com,orfilakfy@gmail.com).

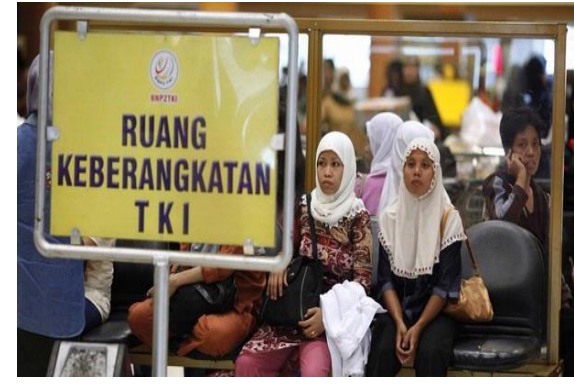

Fig. 1. Indonesian migrant domestic workers.

The Global Alliance Against Traffic in Women (GAATW) States that "the vulnerability of migrants to these human rights abuses can be partly attributed to high levels of undocumented labour migration and unscrupulous practices by labour agents, as well as an apparent 'normalisation' or invibilisation' of exploitation and abuse among employers of domestic workers in some countries" [11]. Indonesian migrant domestic workers are one of the highest rates of undocumented labour migration (see Fig. 2).

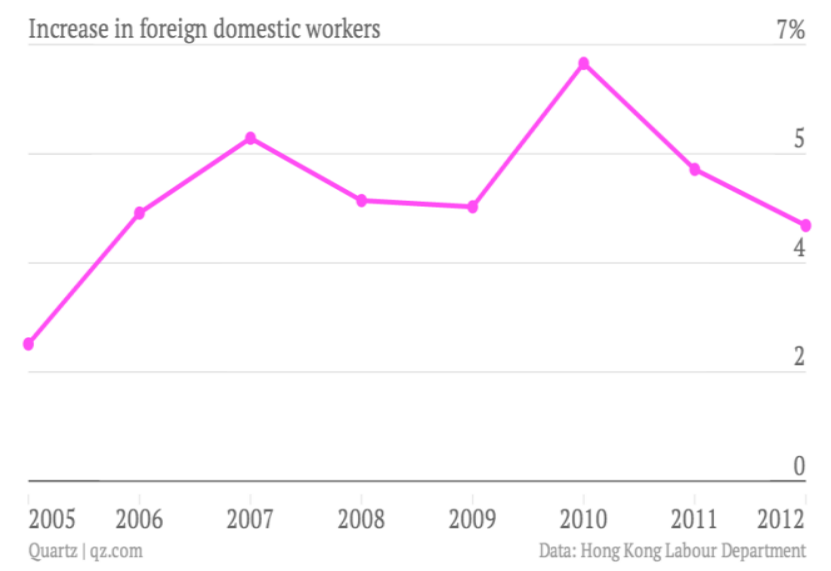

Fig. 2. Asian domestic migrant workers to Hong Kong.

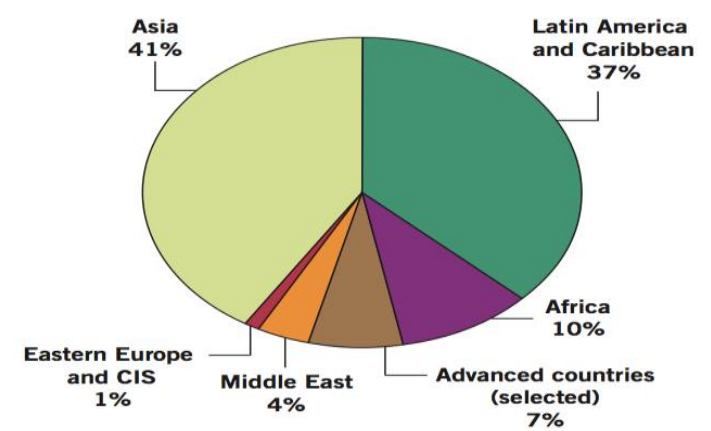

Fig. 3. Estimates of the world's distribution of domestic workers as of 2010 (International Labour Organization). 
The figure above shows the Domestic Migrant Workers mostly women from Asia such as the Philippines, Indonesia, Sri Lanka, Nepal, Bangladesh and Myanmar pour into Hong Kong. The domestic migrant workers do not have high education and they work as housekeepers, nannies and caretakers (see Fig. 3).

The International Labour Organization (ILO) reports that the Indonesian domestic migrant workers have aim to go Saudi Arabia and Malaysia [12]. The US Department of State has estimate that the migrant workers of Indonesia are between 6.5 and nine million, of those, 2.6 million workers go to Malaysia and 1.8 million workers go to the Middle East [13]. The ILO reported that in 2011, the Indonesian migrant workers have the top destination countries such as Saudi Aribia $(n=137,643)$, Malaysia $(n=134,108)$, Taiwan $(n=73,498)$, Hong Kong $(n=50,283)$ and Singapore $(n=47,781)$ [14]. Mostly of them are women and in general, the women works in domestic service approximately 90 percent [15]. The Indonesian migrant workers go to abroad via irregular or undocumented routes [16], [17]. Going to abroad via irregular or undocumented routes of Indonesian migrant domestic workers are one of cause risk of abuse, exploitation and human trafficking (see Fig. 4)

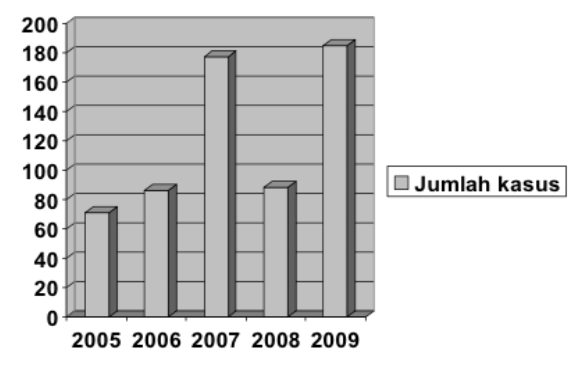

Fig. 4. The cases of human trafficking in Indonesia

\section{RESEARCH PROBLEM}

Exploitation in the fishing, logging, construction, agriculture and commercial sex industries happen in Southeast Asians through work in factories, plantations and as domestic workers in private homes or business [9], [11], (see Fig. 5).

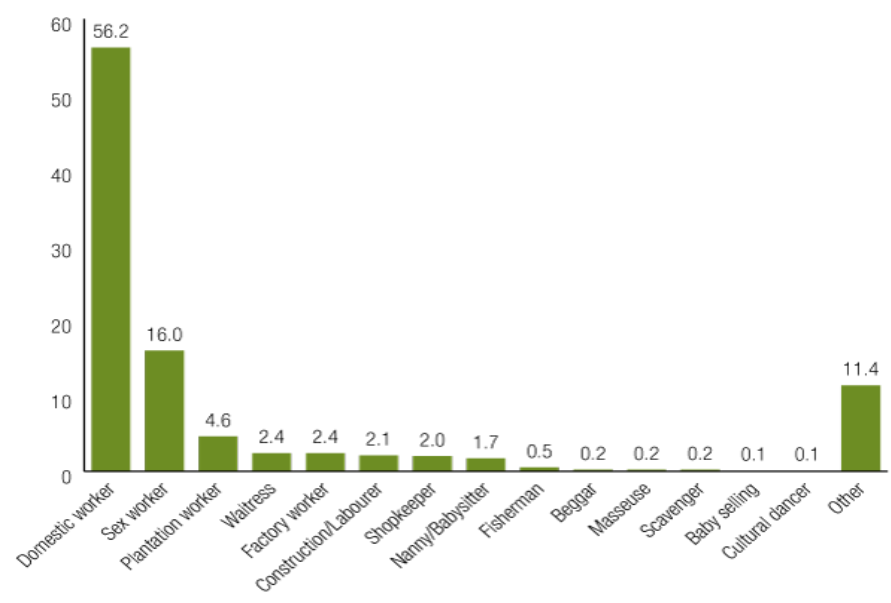

Fig. 5. Type of work undertaken by Indonesian victims of trafficking in final destination country (n).

Source: International Organization of Migration (IOM), 2011

The figure above shows the IOM sample on the type of work of Indonesian workers that were trafficked such as domestic service, sex work, shop keeping, waitressing, dancing and factory work, among several others. Based on data of IOM that "Indonesia has been identified as a key source of trafficked persons in the southeast Asia region, much of which occurs in the context of labour migration and is often undocumented" [18]. Trafficking in person both domestically and transnationally in Indonesia is an issue of concern across Indonesia's 33 provinces especially in Java, West Kalimantan, Lampung, North Sumatera and South Sumatera [18]. Based on Data of IOM that "almost half of the trafficked Indonesians identified Java as their home province $(46 \% ; n=1,714)$. The next largest group originated from West Kalimantan $(20 \%$; $n=722)$, followed by North Sumatra $(7 \% ; n=254)$ with smaller proportions identifying West Nusa Tenggara $(6 \% ; n=237)$, Lampung $(5 \% ; 189)$ and others as their home province" [19]. South Sulawesi Province also has been identified as a trafficking issue within

Indonesia. This province is one of the migrant workers sending areas in Indonesia. The Indonesian government especially governor of South Sulawesi has showed good political will and strategy in countering human trafficking in this area through education sector.

\section{RESEARCH QUESTION}

As a modern form of slavery, human trafficking can be beaten. What can the average person do to help to fight this crime?. How can we better educate potential victims of human trafficking?

\section{METHOD OF RESEARCH}

This research uses qualitative method. This method is to analysis and collects data to support the content of analysis. Hennink et.al. said that qualitative research is "an approach that allows the researcher to identify issues from the perspective of the researcher study participants, and understand the meanings, and interpretations that they give to behavior, events or objects [20]. In collecting data and information, we also conducted depth interview with students as a new generation and government as decision maker. This research conducted in Jeneponto district, South Sulawesi Province. We selected this district for two following reasons: 1) Jeneponto is one of the province in South Sulawesi what sent migrants to abroad, 2) The governor of this district has contribution in countering human trafficking in his area.

\section{ANALYSIS AND DISCUSSION}

In article 1 point 1 of the Law of Republic of Indonesia No.21 Year 2007 on the Eradication of the Criminal Act of Trafficking in Persons states that human trafficking means "the recruitment, transportation, harboring, sending, transfer, or receipt of a person by means of threat or use of force, abduction, incarceration, fraud, deception, the abuse of power or a position of vulnerability, debt bondage or the giving or receiving of payments or benefits to achieve the consent of a person having control over another person, 
whether committed within the country or cross-border, for the purpose of exploitation or which causes the exploitation of a person" [21]. Then, this law in its article 56 also highlights the prevention of trafficking that "at preventing the criminal act of trafficking in persons at the earliest moment possible" [22] (see Fig. 6-Fig. 8). .

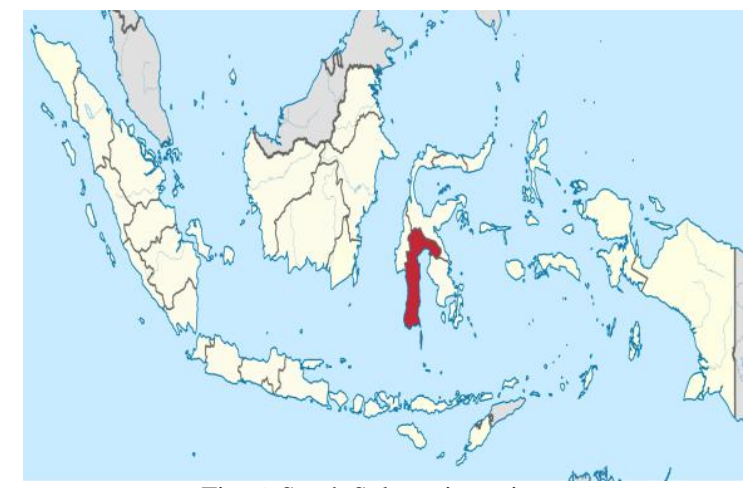

Fig. 6. South Sulawesi province.

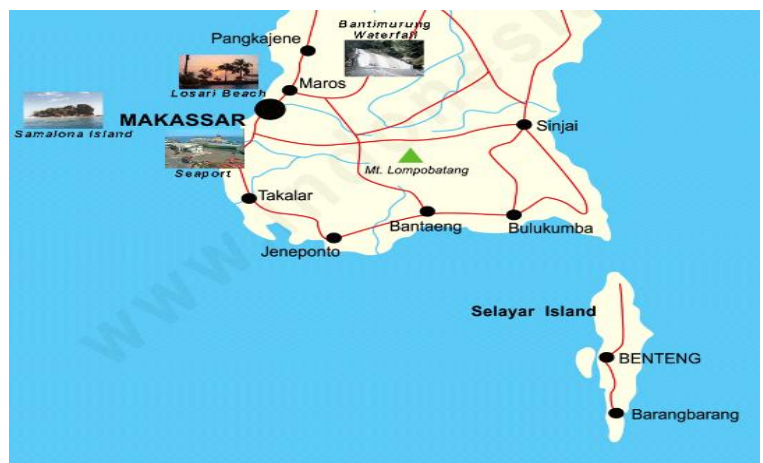

Fig. 7. Jeneponto district in south sulawesi province.

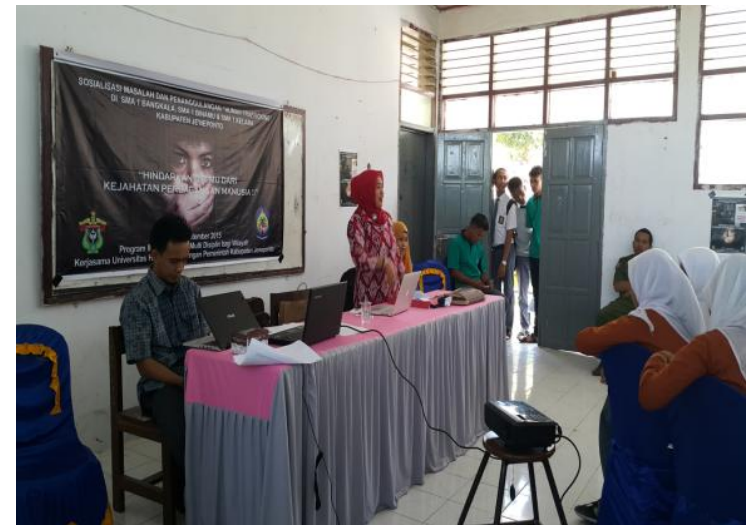

Fig. 8. Workshop on countering human trafficking in senior high school of Bangkala in Jeneponto district, south Sulawesi province.

In beating human traffickers, education and knowledge of trafficking in person among all members of society is one of strategy. As a researcher, we try to raise awareness about the nature, causes and damage to victims. Therefore, cooperation between government, civil society, the press, and private companies in promoting knowledge of countering human trafficking are needed. NGO, researcher and government assist to identify those groups most at risk. The figure 8 is a workshop about how to fight human trafficking. This programme was conducted by researchers from Hasanuddin University. They explain about human trafficking especially sexual exploitation. Women and children especially girls are the most widely become victim for sexual exploitation. As one of victims of this crime, new generation should know risk of being trafficked. Actually, not only girl, but also men and boys are trafficked to the dirty, the dangerous and the difficult jobs.

We shared information about how to fight human trafficking through the above workshop. Based on data BNPPTKI (National Agency for Placement and Protection of Indonesian Overseas Workers) that more than 6.7 million Indonesian migrant workers went to Malaysia and Saudi Arabia [23]. The majority of them have low skill and as domestic workers or plantation workers [24]. In facilitating the migration of Indonesian migrant workers, labour export agencies and brokers have roles to recruit and transport them to another country where they work. Based on Sugiarti's research that South Sulawesi Province is a source areas of migrant workers in Indonesia [25]. The Manpower Office of Nunukan District, East Kalimantan Province said that during period of 2003 and 2004, migrant workers from South Sulawesi were more than 70,000 to Sabah East, Malaysia [26]. This condition puts migrant workers in a vulnerable position to be exploited abroad.

Recognizing the extent of the threat of human trafficking, the Indonesian government has undertaken multilateral efforts through education sector to address this threat.

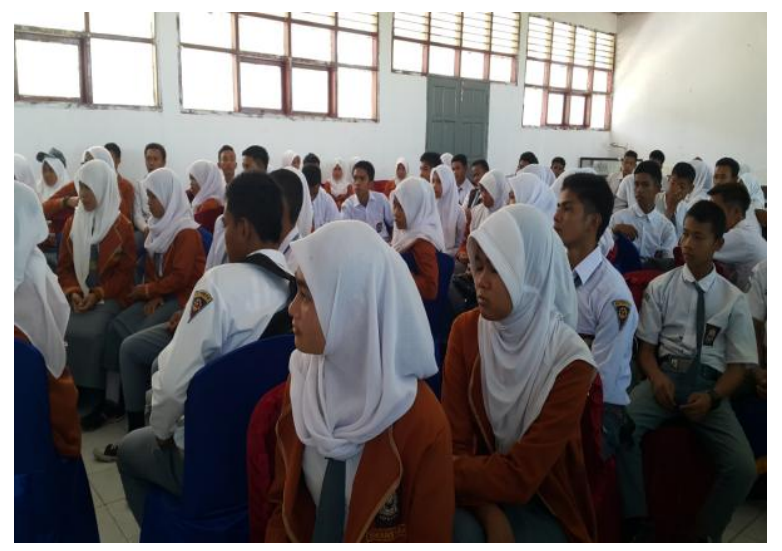

Fig. 9. Workshop on countering human trafficking in senior high school of Bangkala in Jeneponto District, south Sulawesi province.

The researchers share information and knowledge to students about the counter-trafficking in person policy. The Education sector can play in combating modern slavery such as giving information about how to prevent trafficking, prosecute traffickers, and protect and reintegrate victims. Jeneponto District government provides training to local district and local teachers to eradicate this crime. Teacher and student as a representative of education sector are the key actors at the forefront of this fight. They can reduce the vulnerability of potential victims, providing support and assistance to presumed and current victims, and try to implement the strategies of government that address the root causes of trafficking.

\section{CONCLUSION}

In countering human, Jeneponto government through education sector promotes school-to-school cooperation and 
facilitates the exchange of experiences and lesions learned to tackle this issue. By taking action against human trafficking, teachers and students protect their families and friends and promote themselves as being socially responsible.

\section{ACKNOWLEDGEMENTS}

Our thankfulness to Rector Hasanuddin University in giving us fund to support our conference in the abroad and in publishing our research. Finally, we take this opportunity to acknowledge for Hasanuddin university's reviewers in correcting our paper.

\section{REFERENCES}

[1] R. Parrenas and Salazar, "Migrant Filipina domestic workers and the international division of reproductive labor," Gender and Society, vol. 14 , no. 4 , pp. 560-580, 2000.

[2] P. Lan, "Maid or madam? Filipina migrant workers and the continuity of domestic work," Gender and Society, vol.17, no. 2, 187-208, 2003.

[3] Anti-Slavey International. (2006). Trafficking in woman, forced Labour and domestic work in the context of the middle east and gulf region. [Online]. Available: http://www.antislavery.org/includes/documents/cm_docs/2009/t/traffi c_women_forced_labour_domestic_2006.pdf

[4] Human rights watch. (2010). Slow reform: protection of migrant domestic workers in Asia and the middle east. [Online]. Available: http://www.hrw.org/reports/2004/07/21/help-wanted.

[5] Bnpptki. (2012). Penempatan TKI berdasarkan sektor (placement of Indonesian Migran workers based od sector). [Online]. Available: http://BNPPTKI.go.id/statistik-mainmenu-86/penempatan/6757-pene mpatan-berdasar-sektor.html

[6] J. Bustamante. (2007). Mission to Indonesia, Report of the Special Rapporteur on the Human Rights of Migrants. [Online]. Available: http://www.ohchr.org/EN/HRBodies/SP/Pages/AnnualreportsHRC4th .aspx.

[7] (2006b). Using Indonesian law to protect and empower Indonesian migrant workers: Some lessons from the Philippnes. [Online]. Available:

http://www.ilo.org/wcmsp5/groups/public/@asia/@ro-bangkok/@ilojakarta/documents/publication/wcms_1222285.pdf

[8] Global Alliance Against Traffic in Women (GAATW), Moving Beyond 'Supply and Demand' Catchphrases. Assessing the Uses and Limitations of Demand-Based Approaches in Anti-Trafficking. Bangkok: GAATW, 2011.

[9] (2006). Swept under the rug: Abuses against domestic workers around the [Online]. Available: http://www.hrw.org/reports/2004/07/21/help-wanted

[10] (2004). Help wanted: Abused against female migrant domestic workers in Indonesia and Malaysia. [Online]. Available: http://www.hrw.org/reports/2004/07/21/help-wanted

[11] United Nations Office of Drugs And Crime (UNODC), Global Report on Trafficking in Persons, Vienna: UNODC, 2009

[12] (2010). Organization for Security and Co-operation in Europe (OSCE). [Online]. Available: http://www.osce.org/cthb/75804

[13] L. J. Joudo. (2010). Migration and People trafficking in southeast Asia. [Online].

Available: http://aic.gov.au/publications/current\%20series/tandi/401-420/tandi40 1.aspx

[14] Law of Republic of Indonesia, Definition of Human Trafficking, no. 21, 2007.

[15] International Labour Organization (ILO). Domestic Workers in Southeast Asia. A Decent Work Priority. [Online]. Available:
http://www.ilo.org/jakarta/whatwedo/publications/WCMS_122290/la ng-en/index.htm.

[16] (2011). Indonesia. [Online]. Available: http://www.iom.int/jahia/Jahia/indonesia

[17] (2012). 10 Years of Work on Labour Migration in Indonesia. [Online]. Available:

http://www.ilo.org/wcmsp5/groups/public/-asia/-ro-bangkok/-ilo-jakar ta/documents/publication/wcms_213361.pdf

[18] (2013). Domestic workers across the world: Global and regiona statistics and the extent of legal protection. [Online]. Available: http://www.ilo.org/global/publications/books/WCMS_173363/lang-en /index.htm

[19] "Labour migration from Indonesia: An overview of Indonesian migration to selected destinations in Asia and the middle east," International Organization for Migration (IOM), Jakarta: IOM, 2010.

[20] (2012). Indonesia. [Online]. Available: http://www.iom.int/jahia/Jahia/Indonesia.

[21] Hennink, M. Hutter, and I. A. Bailey, Qualitative Research Method, London: Sage Publication, 2011.

[22] US Department of State (US DoS). (2010). [Online]. Available: http://www.state.gov/documents/organization/142979.pdf

[23] Trafficking in Persons Report, $11^{\text {th }}$ ed. Washington: US Department of State, 2011

[24] (2012). Trafficking in person report. [Online]. Available: http://www.state/j/tip/rls/tiprpt/2012/index.htm

[25] Sugiarti and K. Lasmi, "Provincial assessments: South sulawesi," When They were Sold: Trafficking of Women and Girls in 15 Provinces of Indonesia, ICMC Indonesia and Solidarity Center, 2006

[26] R. Parrenas and Salazar, "Migrant Filipina domestic workers and the international division of reproductive labor," Gender and Society, vol. 14 , no. 4 , pp. $560-580.2000$.

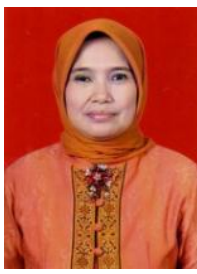

Rahmatia Yunus was born in 1963 in Ujung Pandang, Indonesia. She is working with the Economic Department at the Hasanuddin University, Makassar, South Sulawesi, Indonesia.

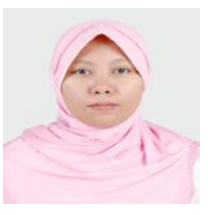

Seniwati was born in 1976 in Makassar, Indonesia. She is working with the International Relations, Social and Political Faculty at the Hasanuddin University, Makassar, South Sulawesi, Indonesia.

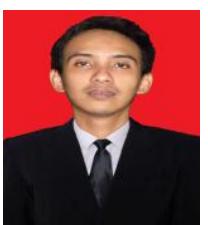

Amanus Khalif filardy Yunus was born in Ujung Pandang, Indonesia. He is working with the Economic Department at the Hasanuddin University, Makassar, South Sulawesi, Indonesia.

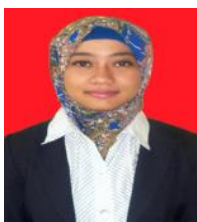

Munawwarah S. Mubarak was born in Ujung Pandang, Indonesia. She is working with the Economic Department at the Hasanuddin University, Makassar, South Sulawesi, Indonesia. 